\title{
The morphological development of lingual papillae at prenatal, postnatal, young and adult stages of white albino mouse
}

Eman El-sayed Mohammed El-nahass*

*Correspondence: emannahass@yahoo.com

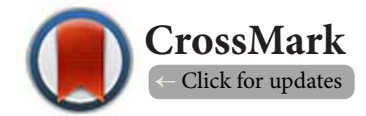

Lecturer of Comparative Anatomy of Vertebrates, Zoology department, Faculty of Science, Tanta University, Egypt.

\begin{abstract}
Purpose: The purpose of this paper is to describe the morphological structure of white albino mice lingual mucosa at the ultra structural level by scanning electron microscopy. Specimens taken from tongue of mice in different developmental stages (prenatal, postnatal, young and adult) and examined after technical procedures.

Results: Our results show that the tongue of these mice has a number of unique morphological features that are different from the tongue of other rodents consequently to allow identifying their speciesspecific features. In fetuses (prenatal stage), the tongue surface showed thickening of epithelium appear as undifferentiated papillae. In newborn (postnatal stage), rudiments of more differentiated papillae begin to appear. In young stage, further differentiation of the epithelium rudiments into developed papillae and this continued to mature in adult stage in which taste buds were observed.

Conclusion: Our findings have shown the features of the tongue structure of white albino mice at the ultra structural level in different developmental stages. The data analysis revealed that mucous membrane of the tongue contains large number of papillae that appear in different stages. Gustatory papillae (fungiform, foliate and vallate) appear in early stages while mechanical ones (filiform and multifilamentary) appear later, each of these papillae has a different shape, size and location. With the advancement of growth, three types of filiform papillae appeared as small-finger like projections with rounded tips associated with much more keratinization of their free ends, well developed foliate and multifilamentary papillae that appear in adult stage. As well as one large and similar smaller circum vallate papillae. The gustatory fungiform papillae appear at early stages of development and were more differentiated gradually till adult stage.
\end{abstract}

However, we have received data for a complete picture of structure of this organ that will be useful in further experimental and morphological studies of white albino mice.

Keywords: Albino mice, lingual mucosa, papillae, scanning electron microscopy, tongue

\section{Introduction}

The morphology of the tongue and papillae widely vary in different species of mammals through the influence of the environment, functional activities and way of capture and manipulation of the food, swallowing, animal care and vocal modulations of animals [1-3].

During embryogenesis of the mouse, the developing tongue divided by terminal sulcus into an oral part anteriorly and pha- ryngeal part posteriorly, its dorsal surface has four types of lingual papillae: fungiform, circumvallate, foliate and filiform that distributed in a specific pattern [4].

Fungiform, foliate and circumvallate ones which known as gustatory papillae and contain taste buds act as sensory organs, these papillae distributed over the tongue surface in a distinct spatial pattern [5]. In central and lateral regions, circumvallate and foliate papillae found respectively but the fungiform ones

(ㄷ) 2019 El-nahass E E; licensee Herbert Publications Ltd. This is an Open Access article distributed under the terms of Creative Commons Attribution License (http://creativecommons.org/licenses/by/3.0). This permits unrestricted use, distribution, and reproduction in any medium, provided the original work is properly cited. 
distributed among the filiform papillae that appear larger and more abundant in a stereotyped array in longitudinal rows on the anterior tongue with the medial rows forming prior to more lateral ones and the more anterior papillae developing first within each row [6].

Tongue mucosa differed markedly from that of the oral cavity in covering by functionally masticatory mucosa lined with different types of lingual papillae [7]. In mammals, taste buds are organized by taste receptor cells that located within specialized papillae $[8,9]$ stated that taste papillae develop prenatal while taste buds appear subsequently within these papillae at the time of parturition in rodents. Thus; the first step in the gustatory system development of mammals is the papillae formation. Taste buds are discrete collections of nearly 40 to 60 cells within epithelial layer of papilla appear as organ with oval sensory end involved in perception of chemical stimuli and taste transduction [10-12].

Vallate papillae are found that were round-flat or long-flat, surrounded by a prominent circular groove and a thin annular pad, one circumvallate papilla is located in the middle part of the terminal sulcus in rodents, about 7 to 9 circumvallate papillae are located along the terminal sulcus in humans. Foliate papillae found posteriorly on the sides of one-third of the human tongue which were well developed at birth but revert to a rudimentary structure in adults; keratinisation of the covering stratified squamous epithelium was relatively weak, taste buds were observed in the epithelium of fungiform, vallate and foliate papillae [6].

Taste buds not found in filiform papillae that cover the entire anterior part of the tongue and consist of cone-shaped structures, each of them with a core of connective tissue covered by an epithelium appearing hair-related keratins [13], it also consist of larger main papillae with smaller secondary papillae on their anterolateral portions, these secondary papillae are well distributed over the anterior two-thirds of the tongue but very rare or absent in the posterior third [6].

The objective of this paper is to describe the research results of the morphological structure of white laboratory albino mice tongue at different stages of development at the ultra structural levels by scanning electron microscopy for obtaining more detailed and complete information about the structure and spatial organization of the tongue.

\section{Material and methods}

The study was conducted on 10 albino mice for each stage (prenatal, postnatal at birth, young at 15 day old and adult), adult and young mice were housed in independent cage units and subject to the full local protocols and scientific research ethics on animals as well as the application of biosafety security requirements and bio-security through the steps of experiments. Each mouse was euthanized followed by scanning electron microscope study: dorsal surface of the tongue that was fixed in $2.5 \%$ buffered gluteraldehyde in $0.1 \mathrm{M} \mathrm{PBS} \mathrm{pH} 7.4$ at $4 \mathrm{C}$ for $2 \mathrm{~h}$. Followed by washing three times with PBS (10 min. each) and Post fixed in 1\% Osmic acid for (30min).

The specimens were washed three times with PBS (10 min. each), then dehydrated with ascending series of ethyl alcohol $(30,50,70,90 \%$ and absolute alcohol) infiltrated with acetone, each concentration for $30 \mathrm{~min}$.

Samples were dried in SPI supplies ${ }^{\circledast}$, critical point drying machine using liquid $\mathrm{CO} 2$, mounted on aluminum stubs, coated with gold in a SPI- Module ${ }^{\mathrm{TM}} \mathrm{Vac} / \mathrm{Sputter}$ and photography using JEOL, JSM- 5200 LV scanning electron microscope, Japan.

\section{Results}

The tongue of white laboratory mice is a well developed muscular organ that has an elongated shape in the rostro-caudal direction with an expanded tip. The intermolar prominence is the widest and thick part of the tongue located between the root and body of the tongue found only in the tongue of adult mice. The median sulcus extends from the tip to the middle of the back of the tongue that appears in young and adult stages only. Presence of a large number of papillae which are different in size, shape and localization on the tongue dorsal surface was observed under scanning electron microscope at different stages.

The dorsal surface in tongue of prenatal mice: is covered by partially keratinized stratified squamous epithelium; different types of undifferentiated papillae are arranged on the dorsal surface of prenatal tongue. These papillae are covered with dense cornification of the epithelium giving polygonal and round shape.

The fungiform papillae are less developed "less differentiated" and resemble a dome-like structure on both lateral surfaces with out any taste buds.

In the middle tongue, small foliate papillae appear but larger ones are located near the root of the tongue. The circum vallate papillae are developed and located among foliate papillae, their form resemble the fungiform ones but smaller in size and have one or two taste bud at middle of it, against fungiform ones they form circum ferential groove around themselves.

In the tongue of new born albino mice, its dorsal surface covered with different types of more developed papillae than that found in prenatal tongue, these papillae appear as small cornified conical papillae in anterior tongue but large cornified foliate papillae at middle and undifferentiated ones appear as keratinized epithelium at posterior tongue that have undeveloped groove with out taste buds.

The fungiform papillae appear to be more differentiated with taste buds "as vallate papillae" and arranged at both lateral sides and middle of the tongue.

In young albino mice, the whole tongue is covered with more organized filiform papillae and fungiform ones with distinguished taste buds.

Primitive intermolar prominence with primitive groove without taste buds begins to appear in this stage as widest and thick part of the tongue located between the root and body of the tongue. The median sulcus also begins to appear and extends from the tip to the middle of the back of the tongue. 
The anterior tongue covered with small long conical and filiform papillae, these filiform papillae branched to give the biramous shape at middle tongue. Well developed vallate and fungiform papillae appear at posterior tongue.

The tongue of adult mice is the most developed and differentiated tongue that have fungiform papillae large and numerous at the tip of the tongue. Well developed small and long conical papillae at the anterior tongue, branched filiform papillae cover the middle tongue.

The well developed intermolar prominence with taste bud and deep groove localized between the root and body of the tongue and formed by foliate papillae which are densely arranged to each other and have sharp splintered apices that covered by keratinized stratified epithelium. The multifilamentary papillae are located behind the intermolar prominence. They have a common base from which one or two or three long and thin filaments depart (Figures A-D).

\section{Discussion}

The results of this study supplement the description of the ultramicroscopic structure of papillae and dorsal surface of the tongue of white laboratory albino mice at different developmental stages, tongue morphology of these mice is substantially similar to the tongue structure of previously studied mammals. However, these results showed that tongue of these mice has a number of unique morphological features different from that of other rodents allow in identifying their species-specific features.

In this study, tongue of white albino mice appear oblong in its shape in the rostro-caudal direction with an expanded tip, while tongue of white laboratory rats and blind mole rats described by $[6,14]$ has an oblong shape and narrows toward the rounded tip at the same time, [15] described tongue of bank vole as oblong with an expanded tip and a narrow back.

Filiform papillae of young and adult albino mice are densely distributed on the dorsal surface of tongue while the distance between them is increased from tip to root of the tongue and become lower and wider, these results similar to that found in white laboratory rats [6].

[14-16] found that filiform papillae of blind mole rat, shrew and bank vole are also densely distributed on the dorsal surface of tongue, but at the same time they are gradually increased in size from the tip to the root of the tongue, these papillae don't appear yet in prenatal and postnatal mice.

On the other hand, fungiform papillae with taste buds in the middle of each one located among filiform ones on the tip of the tongue of all stages of white albino mice either well or less developed but well developed in white laboratory rats, it have a rounded shape and resemble a mushroom cap or dome. In guinea pig, bank vole and flying squirrel, these papillae are located on tip between filiform papillae and lateral surfaces of tongue body while near the edges of the tongue are smaller than in the central part and found only on arch of the tongue in the shrew $[15,17,18]$.

Conical filiform papillae of white laboratory rats, young
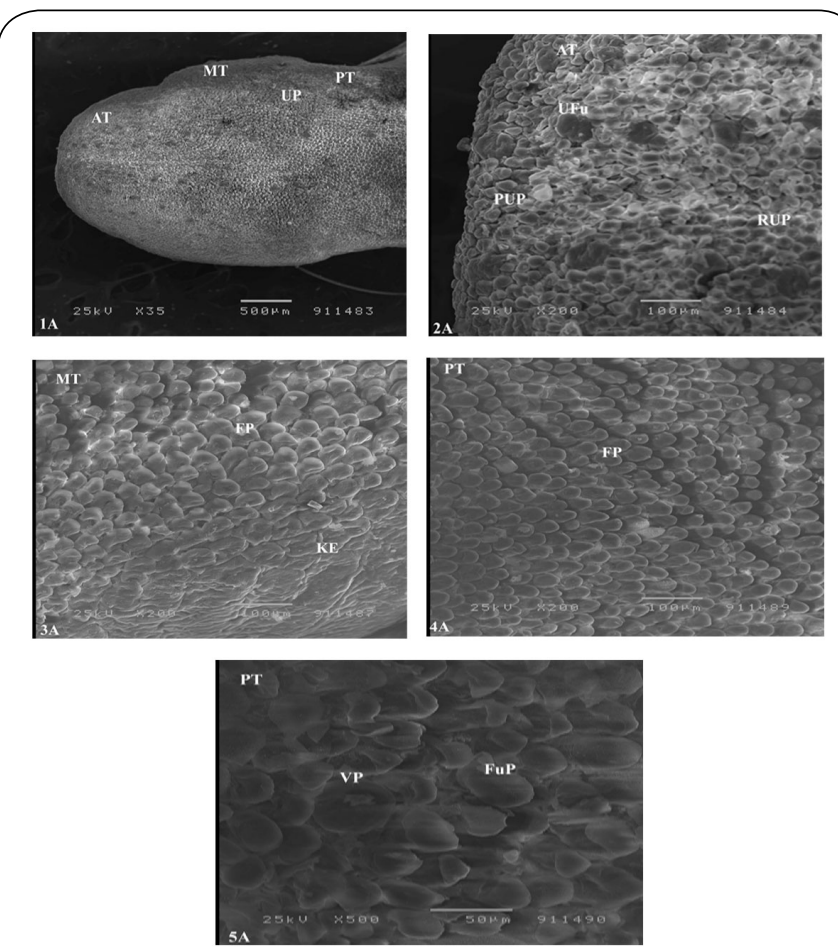

Figure A. The structure of the prenatal tongue of white albino mice.

Fig. 1A: Scanning electron micrograph of the dorsal surface of the whole prenatal tongue of albino mice showing distribution of different types of undifferentiated papillae (UP).

Note: less differentiated (developed) fungiform papillae (UFu) arranged laterally at both sides of the tongue.

Fig. 2A: Scanning electron micrograph of the anterior prenatal tongue of albino mice showing dense cornification of the epithelium giving polygonal (PUP) and round undifferentiated papillae (RUP).

Fig. 3A: Scanning electron micrograph of the middle upper and lower prenatal tongue of albino mice showing small foliate papillae (FP). Note: keratinization of epithelium at lower border of middle tongue (KE).

Fig. 4A: Scanning electron micrograph of the posterior prenatal tongue of albino mice showing foliate papillae (FP). Fig. 5A: Scanning electron micrograph of the posterior prenatal tongue of albino mice showing the difference between vallate $(\mathrm{VP})$ and $(\mathrm{FuP})$ fungiform papillae.

and adult white albino mice have the smaller length and are located on the back near the root on the long distance from each other than the previous filiform papillae. [15] observed that these papillae are the highest and numerous as well and they have the widest basis among all filiform papillae of the tongue of bank vole, while [14] observed these papillae in blind mole rat are long, thin, have irregular shape, pointed and represented by large quantity.

Number of circumvallate papillae among the rodents varied widely, it is large papilla surrounded by roll and located on the posterior part on the medial line of tongue not only in prenatal, young and adult white albino mice but also in white laboratory rat, mouse and bank vole $[19,20]$. 

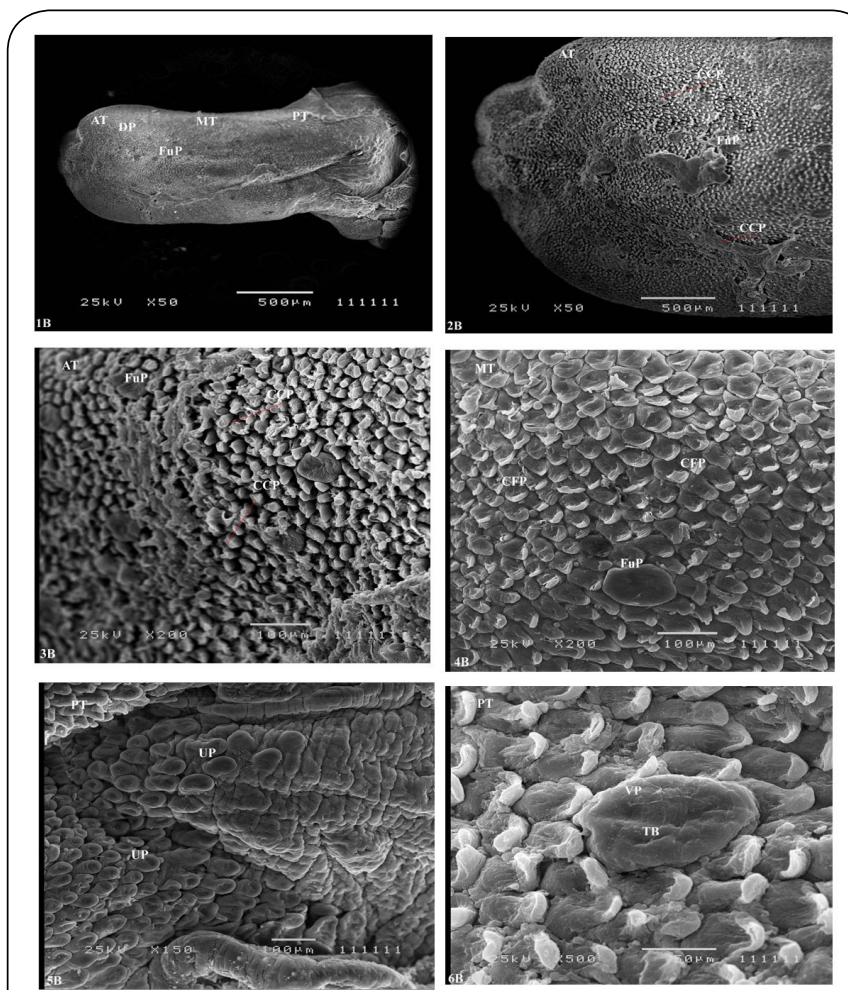

Figure B. The structure of the postnatal tongue of white albino mice.

Fig. 1B: Scanning electron micrograph of the dorsal surface of the whole newborn tongue of albino mice showing distribution of different types of developed cornified papillae (DP). Note: more differentiated (developed) fungiform papillae $(\mathrm{FuP})$ with taste buds arranged laterally at the middle and both lateral sides of the tongue.

Figs. 2,3B: Scanning electron micrographs of the anterior newborn tongue of albino mice showing small cornified conical papillae (CCP).

Fig. 4B: Scanning electron micrograph of the middle newborn tongue of albino mice showing large cornified foliate papillae (CFP).

Fig. 5B: Scanning electron micrograph of the posterior newborn tongue of albino mice showing undifferentiated papillae (UP). Note: undeveloped groove without taste buds. Fig. 6B: Scanning electron micrograph of the posterior newborn tongue of albino mice showing vallate papillae (VP) with taste buds (TB).

Flying squirrel, shrew, and American beavers have three circumvallate papillae $[3,18,21-23]$. Two circumvallate papillae on both sides of posterior part of the tongue are located in blind mole rat and guinea pig $[14,17,22]$.

The roll around papilla formed by thick fold of mucous membrane of the tongue caused by deep circumferential groove formation between bodies of papilla and roll that described in this study, this observation is similar to the studies of $[20,21]$.

In this study, the back of the adult tongue has circumvallate papillae which are similar to the large circumvallate papillae that appear in other stages have been found between the conical filiform papillae, these papillae form the circumferential groove
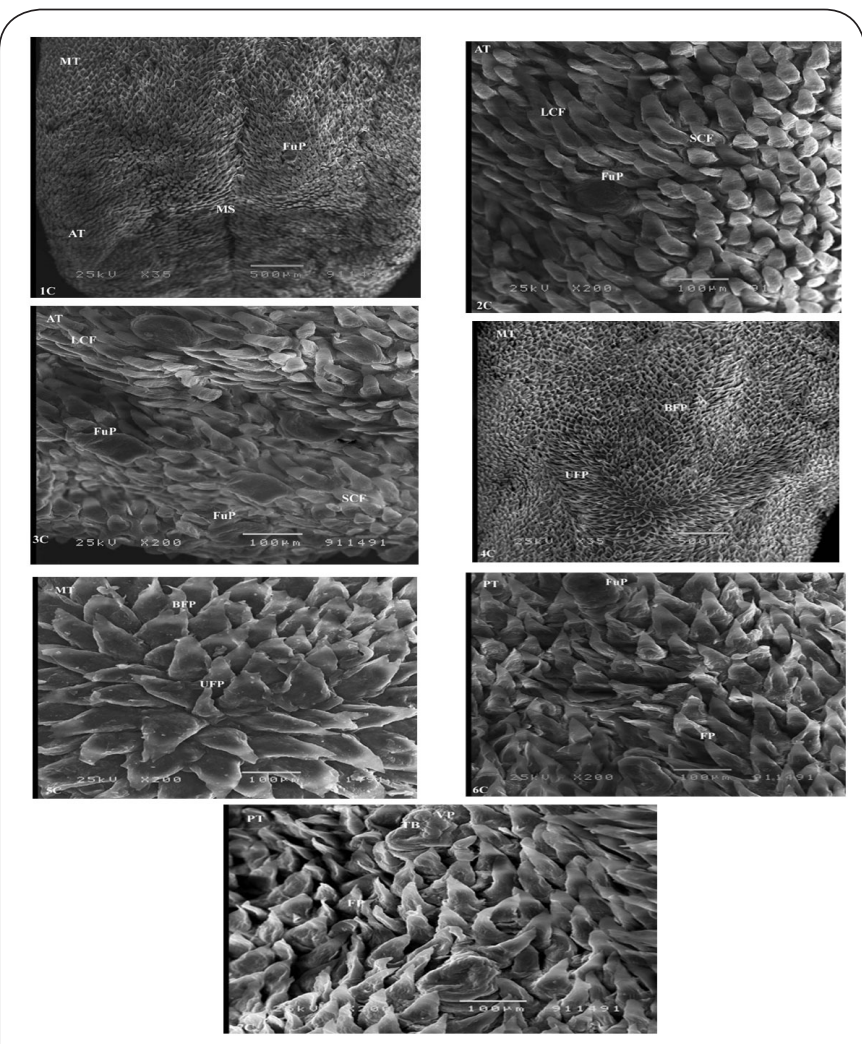

Figure $\mathrm{C}$. The structure of the young tongue of white albino mice.

Fig. 1C: Scanning electron micrograph of the dorsal surface of anterior and middle young tongue of albino mice showing distribution of more organized fungiform papillae $(\mathrm{FuP})$ with distinguished taste buds among different categories of papillae. Note: less differentiated (developed) median sulcus (MS) appear at the half of the tongue.

Figs. 2, 3C: Scanning electron micrographs of the anterior young tongue of albino mice showing small, long conical (LCP) and filiform papillae (FP).

Figs. 4, 5C: Scanning electron micrographs of the middle young tongue of albino mice showing uni (UFP) and biramous (BFP) filiform papillae.

Figs. 6, 7C: Scanning electron micrographs of the posterior young tongue of albino mice showing filiform (FP), vallate $(\mathrm{VP})$ and fungiform papillae (FuP).

around themselves and have one or two taste buds. However not all rodents have these papillae $[20,24,25]$.

$[15,26]$ studied the medial sulcus of the tongue of many rodents and noticed that is of different size and is a typical specific feature, this study showed that the sulcus begin to appear and extends from the tip to the middle of the back of the tongue in young albino mice, but in adult stage, it is well developed. [17] found that these sulcus is absent in guinea pig, but it has structural features in mouse, bank vole and American beavers $[15,19,21,23]$.

Primitive intermolar prominence with primitive groove without taste buds begin to appear in young stage as widest 

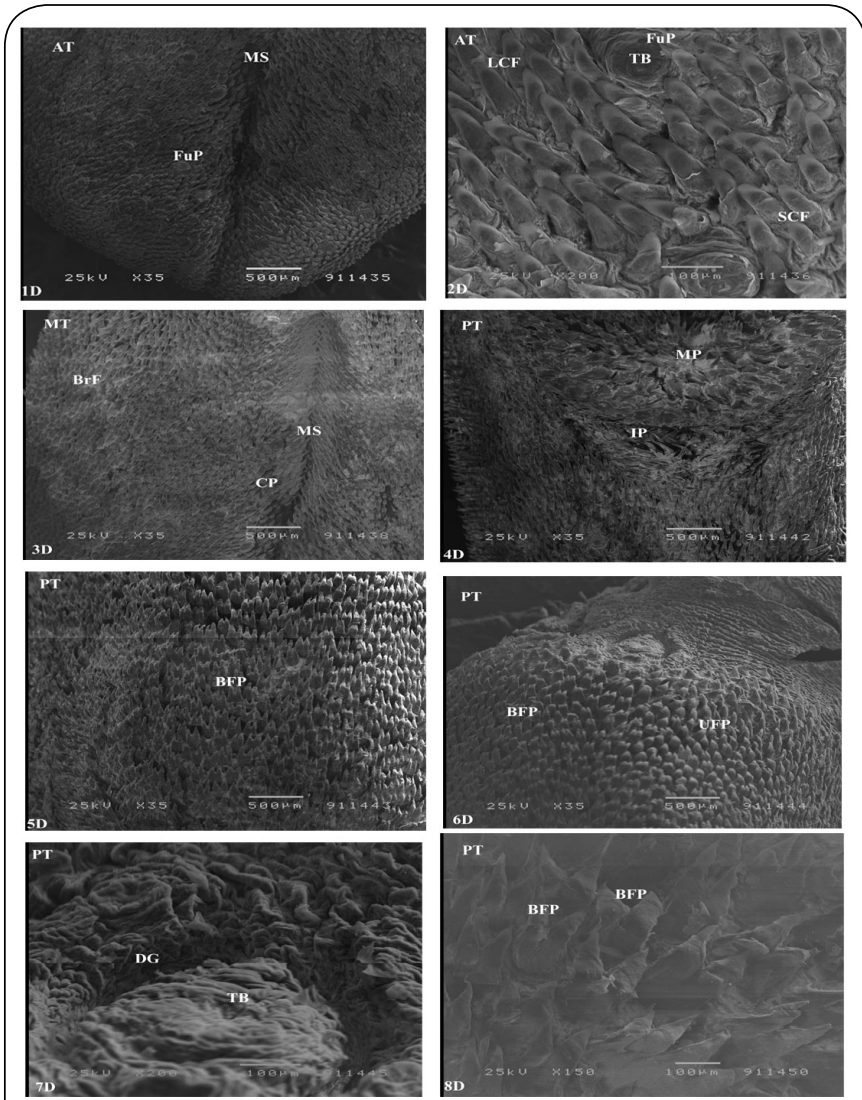

Figure D. The structure of the adult tongue of white albino mice.

Fig. 1D: Scanning electron micrograph of anterior dorsal surface of adult tongue of albino mice showing fungiform papillae (FuP) large and numerous at the tip of the tongue. Note: well developed median sulcus (MS) at the half of the tongue.

Fig. 2D: Scanning electron micrograph of the anterior adult tongue of albino mice showing small (SCF) and long conical papillae (LCF). Note: well developed fungifom papillae with taste buds.

Fig. 3D: Scanning electron micrograph of the middle adult tongue of albino mice showing branched filiform papillae $(\mathrm{BrF})$ on the border and conical papillae $(\mathrm{CP})$ near the median sulcus.

Fig. 4D: Scanning electron micrograph of the posterior adult tongue of albino mice showing intermolar prominence (IP) near the root of the tongue surrounded by multifilamentory papillae (MP).

Fig. 5D: Scanning electron micrograph of the posterior adult tongue of albino mice showing biramous (BFP) and branched filiform papillae.

Fig. 6D: Scanning electron micrograph of the posterior adult tongue of albino mice showing uniramous (UFP) and biramous filiform (BFP) papillae.

Fig. 7D: Scanning electron micrograph of the posterior adult tongue of albino mice showing taste bud (TB) and deep groove (DG).

Fig. 8D: Scanning electron micrograph of the posterior adult tongue of albino mice showing enlarged biramous filiform papillae. and thick part of the tongue located between the root and body of the tongue, but in adult mice, the prominence is formed by massive and wide foliate and branched papillae, this prominence was described by many authors as a lingual prominence formed by the longer filiform and perpendicularly directed papillae [14], but in rats, it formed by the large conical papillae as reported [21].

In addition, we found that the large numbers of special papillae are located behind the intermolar prominence in the caudal regions, it was similar with $[\mathbf{2 1 , 2 5 ]}$ in having a common base from which two in young or three, four and sometimes five long filaments depart in adult, so they were named as multifilamentary papillae and located between foliate and circumvallate papillae.

[21] have noted that the filiform papillae are located behind the intermolar prominence, the apices of which are branched to form several slender twigs.

It has been found that one or several taste buds have a lot of nerve fibers (nerve endings) located in each fungiform papilla and circumvallate papilla, this finding highlights the importance of mice in having developed taste and sensory organs including tongue due to the food habits, their behavior and nocturnal nature.

\section{Conclusions}

Our findings have shown the features of the tongue structure of white albino mice in different stages at ultrascopic levels. The data analysis revealed that mucous membrane of the tongue contains a large number of papillae, such as fungiform, three types of filiform, well developed foliate and multifilamentary papillae, as well as one large and similar smaller circumvallate papillae. Each of them has a different shape, size, and location. However, we have received data for a complete picture of structure of tongue that will be useful in further experimental and morphological studies of the white albino mice.

\section{Competing interests}

The author declares that he has no competing interests.

\section{Publication history}

Editor: Giuseppe Musumeci, University of Catania, Italy. Received: 14-Sept-2019 Final Revised: 25-Oct-2019 Accepted: 05-Nov-2019 Published: 17-Nov-2019

\section{References}

1. Levin MJ and Pfeiffer CJ. Gross and microscopic observations on the lingual structure of the Florida Manatee Trichechus manatus latirostris. Anat Histol Embryol. 2002; 31:278-85. I Article I PubMed

2. Yoshimura K, Shindo J, Miyawaki Y, Kobayashi K and Kageyama I. Scanning electron microscopic study on the tongue and lingual papillae of the adult Spotted seal, Phoca largha. Okajimas Folia Anat Jpn. 2007; 84:8397. I Article I PubMed

3. Pastor JF, Barbosa M and De Paz FJ. Morphological study of the lingual papillae of the giant panda (Ailuropoda melanoleuca) by scanning electron microscopy. J Anat. 2008; 212:99-105. I Article I PubMed Abstract | PubMed FullText 
4. Iwasaki S, Yoshizawa $\mathrm{H}$ and Kawahara I. Ultrastructural study of the relationship between the morphogenesis of filiform papillae and the keratinisation of the lingual epithelium in the rat. J Anat. 1999; 195 ( Pt 1):27-38. | Article | PubMed Abstract | PubMed FullText

5. Mbiene JP, Maccallum DK and Mistretta CM. Organ cultures of embryonic rat tongue support tongue and gustatory papilla morphogenesis in vitro without intact sensory ganglia. J Comp Neurol. 1997; 377:324-40. | Article I PubMed

6. Davydova L, Tkach G, Tymoshenko A, Moskalenko A, Sikora V, Kyptenko L, Lyndin M, Muravskyi D, Maksymova O and Suchonos O. Anatomical and morphological aspects of papillae, epithelium, muscles, and glands of rats' tongue: Light, scanning, and transmission electron microscopic study. Interv Med App/ Sci. 2017; 9:168-177. | Article | PubMed Abstract I PubMed FullText

7. Ten Cate AR. Oral histology: development, structure and function. 4th ed. Saint Louis, CV Mosby Company. 1994.

8. Mistretta C M. Developmental neurobiology of the taste system. Taste and Smell in Health and Disease. T. V. Getchell. New York, Raven Press. 1991; 35-64.

9. Paulson RB, Hayes TG and Sucheston ME. Scanning electron microscope study of tongue development in the CD-1 mouse fetus. J Craniofac Genet Dev Biol. 1985; 5:59-73. I PubMed

10. Barlow LA and Northcutt RG. The role of innervation in the development of taste buds: insights from studies of amphibian embryos. Ann NY Acad Sci. 1998; 855:58-69. | Article I PubMed

11. Oakley B. Taste neurons have multiple inductive roles in mammalian gustatory development. Ann. N. Y. Acad. Sci. 1998; 855:50-57.

12. Barlow LA. A taste for development. Neuron. 1999; 22:209-12. | Article | PubMed

13. Dhouailly D, Xu C, Manabe M, Schermer A and Sun TT. Expression of hair-related keratins in a soft epithelium: subpopulations of human and mouse dorsal tongue keratinocytes express keratin markers for hair-, skin- and esophageal-types of differentiation. Exp Cell Res. 1989; 181:141-58. | Article | PubMed

14. Kilinc M, Erdogan S, Ketani S and Ketani MA. Morphological study by scanning electron microscopy of the lingual papillae in the Middle East blind mole rat (Spalax ehrenbergi, Nehring, 1898). Anat Histol Embryol. 2010; 39:509-15. | Article | PubMed

15. Jackowiak $\mathrm{H}$ and Godynicki S. The distribution and structure of the lingual papillae on the tongue of the bank vole Clethrinomys glareolus. Folia Morphol (Warsz). 2005; 64:326-33. I PubMed

16. Iwasaki S, Miyata K and Kobayashi K. Comparative studies of the dorsal surface of the tongue in three mammalian species by scanning electron microscopy. Acta Anat (Basel). 1987; 128:140-6. | $\underline{\text { Article I PubMed }}$

17. Kobayashi $\mathrm{K}$. Three-dimensional architecture of the connective tissue core of the lingual papillae in the guinea pig. Anat Embryol (Berl). 1990; 182:205-13. | Article | PubMed

18. Emura S, Tamada A, Hayakawa D, Chen H, Jamali M, Taguchi $\mathrm{H}$ and Shoumura S. SEM study on the dorsal lingual surface of the flying squirrel, Petaurista leucogenys. Ann Anat. 1999; 181:495-8. | Article | PubMed

19. Kobayashi K, Miyata K, Takahashi K and Iwasaki S. [Three-dimensional architecture of the connective tissue papillae of the mouse tongue as viewed by scanning electron microscopy]. Kaibogaku Zasshi. 1989; 64:523-38. | PubMed

20. Jackowiak H. Scanning electron microscopy study of the lingual papillae in the European mole (Talpa europea, L., Talpidae). Anat Histol Embryol. 2006; 35:190-5. | Article | PubMed

21. Iwasaki S, Yoshizawa $\mathrm{H}$ and Kawahara I. Study by scanning electron microscopy of the morphogenesis of three types of lingual papilla in the rat. Anat Rec. 1997; 247:528-41. I Article I PubMed

22. Zuri I, Kaffe I, Dayan D and Terkel J. Incisor adaptation to fossorial life in the blindmole-rat, Spalax ehrenbergi. J. Mammal. 1999; 80:734-741.

23. Shindo J, Yoshimura K and Kobayashi K. Comparative morphological study on the stereo-structure of the lingual papillae and their connective tissue cores of the American beaver (Castor canadensis).
Okajimas Folia Anat Jpn. 2006; 82:127-37. | Article | PubMed

24. Utiyama C, Watanabe I, Konig B, Koga L Y, Semprini M and Tedesco R C. Scanning electron microscopic study of the dorsal surface of the tongue of Calomys callosus mouse. Ann. Anat. 1995; 177: 569-572.

25. Reginato Gde S, Bolina Cde S, Watanabe IS and Ciena AP. Threedimensional aspects of the lingual papillae and their connective tissue cores in the tongue of rats: a scanning electron microscope study. ScientificWorldJournal. 2014; 2014:841879. | Article I PubMed Abstract I PubMed FullText

26. Jackowiak H, Godynicki S, Jaroszewska M and Wilczynska B. scanning electron microscopy of lingual papillae in the common shrew, Sorex araneus, L. Anat Histol Embryol. 2004; 33:290-3. I Article I PubMed

\section{Citation:}

El- nahass EEM. The morphological development of lingual papillae at prenatal, postnatal, young and adult stages of white albino mouse. J Histol Histopathol. 2019; 6:6. http://dx.doi.org/10.7243/2055-091X-6-6 